\title{
Removal of chromium (VI) from water by micro-alloyed aluminium composite (MAIC) under flow conditions
}

\author{
A Lj Bojic*, M Purenovic and D Bojic \\ Department of Chemistry, the Faculty of Mathematics and Natural Sciences, University of Niš, Višegradska 33, 18000 Niš, Serbia
}

\begin{abstract}
This paper deals with $\mathrm{Cr}(\mathrm{VI})$ ion removal from water, by micro-alloyed aluminium composite (MAIC), under flow conditions. In a water environment the MAlC acts as a strong reducing agent. Dissolving it in water is accompanied by the generation of $\mathrm{Al}(\mathrm{III})$ ions and reduction of water to $\mathrm{H}_{2}$, with $\mathrm{OH}^{-}$ions. The final product is insoluble $\mathrm{Al}(\mathrm{OH})_{3}$. A series of $\mathrm{Cr}(\mathrm{VI})$ model solutions, with initial $\mathrm{pH}$ ranging between 1 and 5, were treated in the original semi-flow system (SFS), which simulated flow conditions well. The results demonstrate a high MAlC efficacy, considering that at the end of the treatment, concentrations of $\mathrm{Cr}(\mathrm{VI})$ were below the maximal allowed concentrations for drinking water, in all model solutions. The MAlC mechanism of action is based mainly on processes of reduction and co-precipitation by $\mathrm{Al}(\mathrm{OH})_{3}$, because $\mathrm{Cr}(\mathrm{VI})$ is removed from the water phase as metal chromium and insoluble $\mathrm{Cr}(\mathrm{OH})_{3}$. Behaviour of the composite in water is under significant influence of $\mathrm{pH}$, which affects its efficacy and mechanism of action. Therefore, the rate of $\mathrm{Cr}(\mathrm{VI})$ removal is greater at the beginning, decreasing towards the end of the treatment. Additionally, the ratio of [metal chromium] $/\left[\mathrm{Cr}(\mathrm{OH})_{3}\right]$ in precipitate, at the end of the treatment, decreases with increasing initial $\mathrm{pH}$ of the model solution. Application of the SFS significantly enlarges efficacy of the MAlC, compared to work under stationary conditions.
\end{abstract}

Keywords: chromium (VI) removal, wastewater, micro-alloyed aluminium, reduction, co-precipitation, flow conditions

\section{Introduction}

Chromium is present in the environment in both trivalent and hexavalent oxidation states. $\mathrm{Cr}$ (III) occurs naturally and is an essential micronutrient (requirement is 50 to $200 \mu \mathrm{g}$ per day) that assists the body in metabolising sugar, protein and fat. $\mathrm{Cr}(\mathrm{VI})$ is usually of anthropogenic origin and rarely occurs naturally (Barceloux, 1999; Barnhart, 1997). Chromium-plating processes are the main source of $\mathrm{Cr}(\mathrm{VI})$ pollution. $\mathrm{Cr}(\mathrm{VI})$ is a skin and mucous membrane irritant and some of these hexavalent compounds produce an allergic contact dermatitis characterised by eczema (Hassmanova et al., 2000; Kanerva et al., 2000); it is also recognised as a pulmonary carcinogen (Barceloux, 1999; Hassmanova et al., 2000). Because of these potential health hazards the maximum level of $\mathrm{Cr}(\mathrm{VI})$ allowed in drinking water is 0.05 $\mathrm{mgCr} \cdot \ell^{-1}$ (Standard Methods, 1995). The remediation of $\mathrm{Cr}(\mathrm{VI})-$ contaminated industrial effluents is gaining great interest due to limitations in potable water supplies. The main strategies for $\mathrm{Cr}(\mathrm{VI})$ removal from wastewaters are precipitation as $\mathrm{Cr}(\mathrm{OH})_{3}$ (Paterson, 1975; Cooney et al., 1992) and ion exchange (Tenorio and Espinosa, 2001). In addition, there are other options such as sorption onto various materials (Mesuere and Fish, 1992; Leinonen and Lehto, 2001; Selvi, 2001) and membrane flltration (Bohdziewicz, 2000; Alliane et al., 2001).

This study investigated a new treatment process for the removal of $\mathrm{Cr}(\mathrm{VI})$ from aqueous solutions by applying MAlC, under flow conditions. The composite consists of micro-alloyed aluminium

\footnotetext{
* To whom all correspondence should be addressed.

缅+381 64 229-36-40; fax:+381 18533-014; e-mail: bojic@ bankerinter.net Received 16 January 2004; accepted in revised form 5 March 2004.
}

(MAl), coated over a thin iron wire. In aqueous solutions, it behaves like a strong reducing agent, which may affect various pollutants in water. Additionally, as a final product of the MAl, dissolution, water-insoluble $\mathrm{Al}(\mathrm{OH})_{3}$ is produced, which may coprecipitate pollutants and their degradation products from the water phase (Bojic, 1997; Purenovic et al., 1998; Novakovic et al., 1998).

Previous studies (Bojic, 1997; Purenovic et al., 1998; Novakovic et al., 1998), which deal with purification of different wastewaters, show great MAlC efficacy. After water treatments, concentrations of pollutants were reduced for several logs in a relatively short period, and in many cases, they were below the maximum allowed concentrations. The major factors significant for MAlC efficacy are treatment time, the total area of applied composite wires and water convection. The influence of convection is obvious from previous studies which showed that composites have greater efficacy under flow conditions than under stationary conditions (Bojic et al., 2001; Bojic, 2002). Flow systems, applied in some experiments, were massive and impractical for laboratory work and therefore in this study an original semi-flow system was designed, which simulates flow conditions in small spaces (Bojic et al., 2001; Bojic, 2002). Mechanisms of MAlC action on various inorganic and organic compounds (Bojic, 1997; Purenovic et al., 1998; Novakovic et al., 1998), as well as micro-organisms in water (Bojic et al., 2001; Bojic, 2002), were also investigated. It is mainly based on reduction and hydrolysis. It is important to emphasise that in all prior studies no undesirable by-products were found in the water phase after treatment.

The results obtained in this work show that the MAlC treatment of $\mathrm{Cr}(\mathrm{VI})$ wastewaters is very efficient, simple and does not acquire any pretreatment, such as $\mathrm{pH}$ correction. 


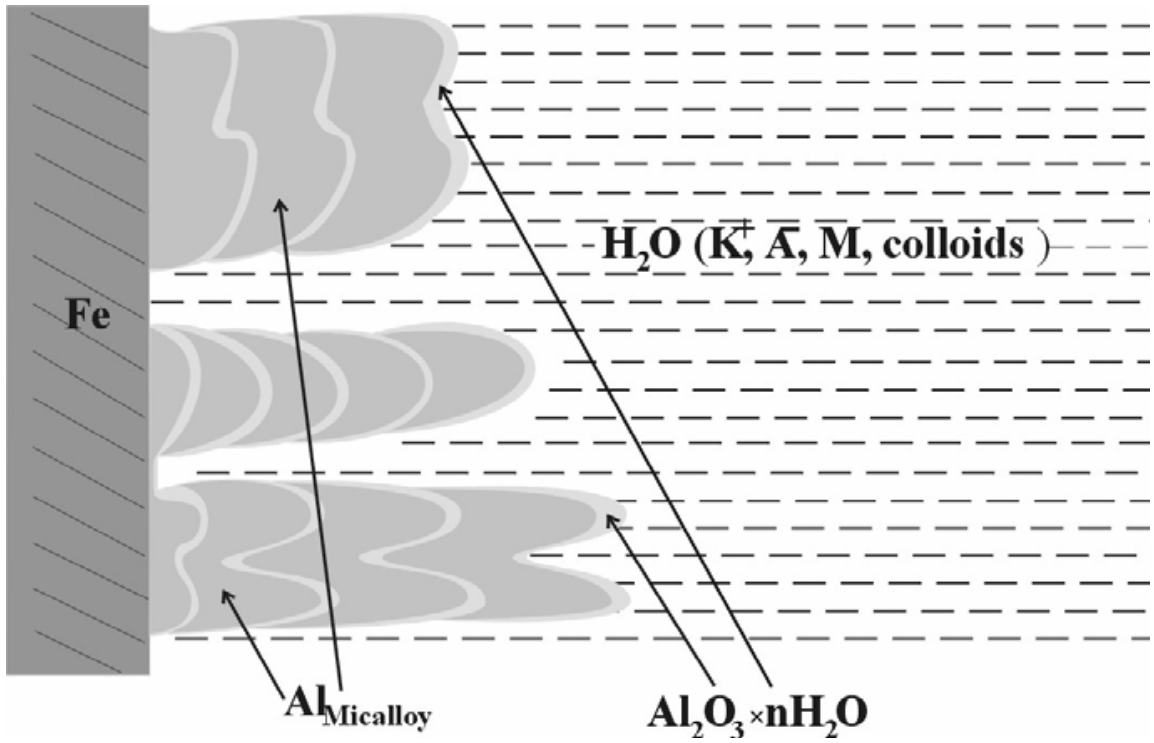

Figure 1

A model of the MAIC

structure in aqueous medium

\section{Experimental}

\section{Chemicals}

The experiments were carried out with the model solutions, the composition of which correlates with the composition of effluent waters from a chromium-plating industry. These wastewaters usually contain $\mathrm{Cr}(\mathrm{VI})$ ion in concentration ranges between 25 and 300 $\mathrm{mgCr} \cdot \ell^{-1}$. Considering that the $\mathrm{pH}$ of a chromic plating bath is between 0 and 1 , because of the presence of sulphuric acid, $\mathrm{pH}$ of the chromium-plating wastewaters varies between 2 and 4 (Lowe, 1970; Paterson, 1975).

The model solutions were prepared by diluting $1.00 \mathrm{gCr} \cdot \ell^{-1}$ stock solution of $\mathrm{Cr}(\mathrm{VI})$, and adjusting the $\mathrm{pH}$ with diluted $\mathrm{H}_{2} \mathrm{SO}_{4}$, pH-metrically. A stock solution was obtained by dissolving the exact quantity of $\mathrm{K}_{2} \mathrm{Cr}_{2} \mathrm{O}_{7}$ in $1.00 \ell$ of deionised distilled water. The series of model solutions, containing $150 \mathrm{mgCr} \cdot \ell^{-1}$ of $\mathrm{Cr}(\mathrm{VI})$, with pH 1.00 (I), 2.00 (II), 3.00 (III), 4.00 (IV), and 5.00 (V), were prepared.

All chemicals were obtained from Merck (Darmstadt, Germany), unless otherwise indicated.

\section{MAIC composite}

The MAl is a new material with different properties compared to pure aluminium. It is prepared by micro-alloying $99.8 \%$ purity aluminium with: Sn, Ga and Bi (Purenovic, 1978; Purenovic, 1992). After micro-alloying, the obtained material was analysed by flame atomic absorption spectroscopy (FAAS) using a VARIAN SpectrAA-20 (Mulgrave, Victoria, Australia), and amounts of metals found were: $0.105 \% \mathrm{Sn}, 0.098 \% \mathrm{Ga}$ and $0.040 \% \mathrm{Bi}$.

By micro-alloying the oxide layer of aluminium, it becomes porous and permeable for ions, because of the many defects in the crystal lattice due to different dimensions and charges of microalloyed elements, related to $\mathrm{Al}^{3+}$ (Despic et al., 1976; Purenovic, 1978). Micro-alloyed components generate defects in a metal structure (interstitials and vacancies in crystal lattice) and an imbalance in the charge distribution, as a result of many microgalvanic cells. These defects decrease energy barriers for transport of $\mathrm{Al}^{3+}$ ion from metal to oxide layer, and $\mathrm{O}^{2-}$ ion from oxide to metal. An after-effect is an increase in ionic and electronic conductivity by $10^{4}$ to $10^{6}$ times, and increase of corrosion rate for almost the same order of magnitude (Purenovic, 1978; Purenovic, 1992). Accordingly, the stationary potential of the MAl is negative, about
$-1.5 \mathrm{~V} / \mathrm{SCE}$ (saturated calomel electrode), and this makes the MAl chemically much more reactive than pure aluminium. A basic characteristic of the MAl is its very negative stationary potential, compared to pure aluminium, and because of that its first usage was anodic anti-corrosion protection of iron (Purenovic, 1980).

The composite was made by metalising an iron wire (mesh $1.2 \times 1.2 \mathrm{~mm}, \varnothing 0.6$ ) with MAl, by means of a special gas burner (Metco, USA) (Purenovic, 1992). The obtained material has an amorphous surface area, the micro-porosity being in the form of fish scales, and offers convenient sites and a large specific surface area for the adsorption of different ions, molecules and colloids dissolved in water. MAlC in aqueous medium is presented in Fig. 1.

Besides many local micro-galvanic cells in MAl, there is also a macro-galvanic cell, Fe $\mid \mathrm{Al}_{\text {Micalloy }}$ (Fig. 1). The MAl and iron composite (author to check) additionally decreases the potential of MAl, which leads to enhancement of the dissolution rate and anode activity (Despic et al., 1976; Purenovic, 1992).

The influence of the composite on water pollutants is based on its spontaneous reaction with water, similar to the reaction of alkaline and earth metals (Purenovic, 1992; Bojic, 1997). The main process on micro-anodes is dissolution of aluminium with the generation of $\mathrm{Al}(\mathrm{III})$ ions, by oxidation of $\mathrm{Al}$ via $\mathrm{Al}^{+}$, and $\mathrm{Al}^{2+}$ stages. The main process on micro-cathodes is reduction of water to $\mathrm{H}_{2}$, via $\mathrm{H}$ - stage, in the process releasing $\mathrm{OH}^{-}$ions (Cotton and Wilkinson, 1972; Purenovic, 1978). Every particle, besides water molecules, which come to the surface of the composite, may became a participant in the many chemical processes (reduction, hydrolysis, addition). $\mathrm{Al}(\mathrm{III})$ and $\mathrm{OH}^{-}$ions form insoluble aluminium-hydroxide. It coagulates to form a gelatinous, voluminous colloidal precipitate with a distinctly developed surface area, a common reagent for the co-precipitation (Voyutsky, 1978). Usually, low amounts of pollutants, as products of their chemical degradation by the MAlC, become co-precipitated by the aluminium-hydroxide during the treatment and removed from the water phase (Purenovic, 1992; Bojic, 1997; Purenovic et al., 1998; Novakovic et al., 1998; Bojic, 2002).

\section{Laboratory equipment}

The treatments of the MAlC model solutions were performed in the original semi-flow system (Bojic, 2002). Equipment, shown schematically in Fig. 2, consisted of several parts. The main bath (MB) made of high-density polyethylene, held a volume of $10.0 \ell$ 


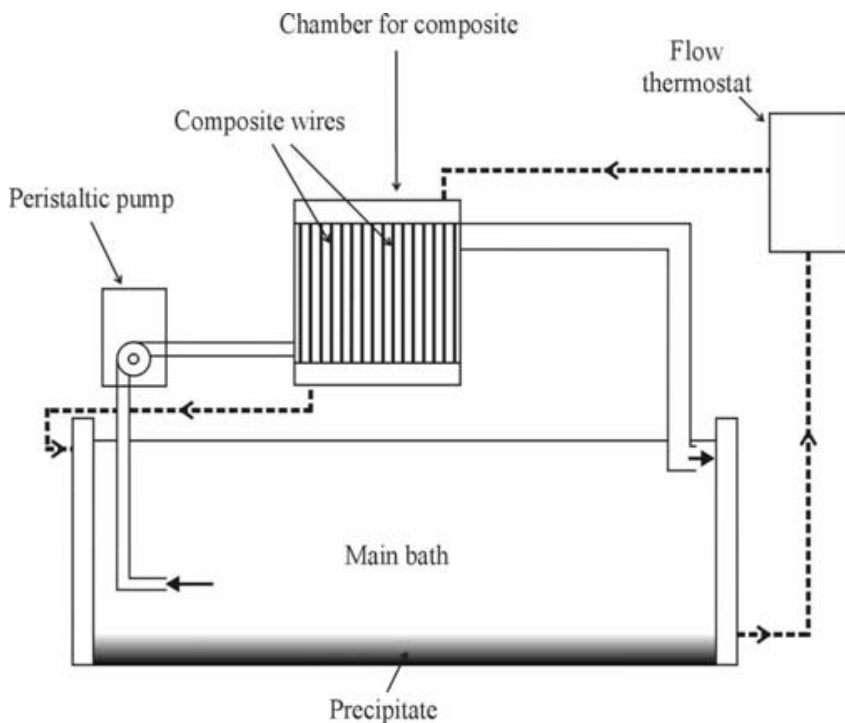

Figure 2

Schematic diagram of the original semi-flow system

solution, while the composite chamber (CC), also of high-density polyethylene, had a volume of $1.0 \mathrm{l}$. Sixteen composite wires, dimension $100 \times 100 \mathrm{~mm}$, placed to the perpendicular direction of water flow in $\mathrm{CC}$, and the peristaltic pump for injecting of solution from $\mathrm{MB}$ to $\mathrm{CC}$, with flow rate maintained at $90 \ell \cdot \mathrm{h}^{-1}$.

$\mathrm{CC}$ was located at $50 \mathrm{~mm}$ above the water level in the MB (Fig. 2). Its frontal side was connected, at the bottom, with a peristaltic pump by means of polyethylene pipe $(\varnothing 20 \mathrm{~mm})$. The horizontal end of the tube entering the peristaltic pump was immersed at about $70 \mathrm{~mm}$ from the bottom end of the MB (Fig. 2), to prevent plugging of $\mathrm{Al}(\mathrm{OH})_{3}$ precipitate formed during the treatment. Solutions from the $\mathrm{CC}$ were continuously returned to the $\mathrm{MB}$ by overflow pipe ( $\varnothing 40 \mathrm{~mm}$ ), which formed a closed loop (Bojic, 2002). The temperature was kept constant by flow thermostat, connected to the water jackets of the MB and the $\mathrm{CC}$.

With a limited number of composite wires in a relatively small area, normal flow conditions were simulated by passing the model solution through the composite chamber a number a times. In comparison, the flow system can be presented as a long CC, with water flowing over it continuously. Such equipment is much larger than the SFS, and comprises a few hundred composite wires. The requisite volume of solutions has to be about 40 to $50 \ell$, because of the necessity of the initial chemical "activation" of wire surfaces, and filling of the system with fluid. On the other hand, the SFS is more efficient than stationary conditions (Bojic, 1997; Novakovic et al., 1998, Purenovic et al., 1998), where the composite wires are simply immersed in the solution contained in the vessel.

\section{Experimental procedure}

$8.0 \ell$ of each model solution was equilibrated at $20^{\circ} \mathrm{C}$, and transferred to the main bath. After taking the zero probes (time 0 $\mathrm{min}$ ), the peristaltic pump and thermostat were run. Samples of the model solutions for analysis were withdrawn every $15 \mathrm{~min}$ from the MB by pipette, transferred to flasks with glass stoppers and left to stand for the $\mathrm{Al}(\mathrm{OH})_{3}$ to precipitate. The MAlC treatment time was determined in terms of the nature of each pollutant and its initial concentration, and it was set to $120 \mathrm{~min}$. During the treatment, $\mathrm{pH}$ was monitored, by $\mathrm{pH}-$ meter Corning Checkmate Modular Testing System (Corning, USA), with a combined electrode. All experiments were performed in triplicate on the same model solution.

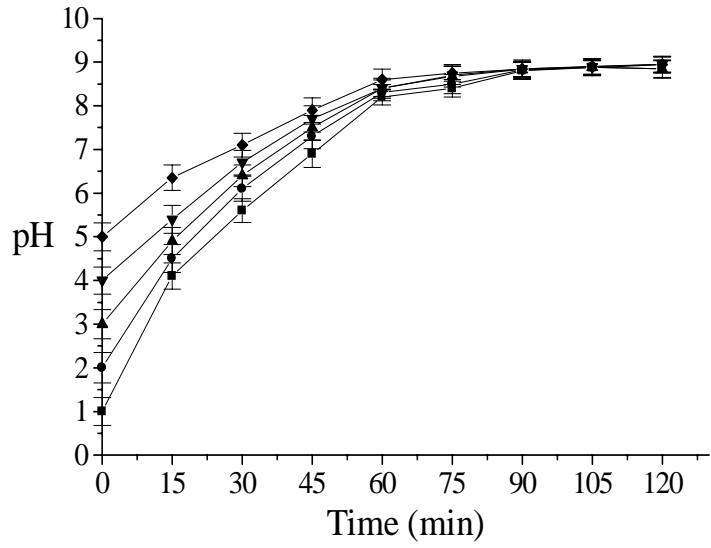

Figure 3

Monitoring of $\mathrm{pH}$ in the model solutions with initial $\mathrm{pH}: 1.00(-)$ $2.00(\bullet), 3.00(\mathbf{\Delta}), 4.00(\mathbf{v})$ and $5.00(\bullet)$, during the treatment by the MAIC, in the semi-flow system at $20^{\circ} \mathrm{C}$. Error bars represent the standard deviation of mean values of the triplicate sample.

At the end of the treatment, the composite wires were removed from the CC. It was noted that black amorphous powder of reduced metal chromium, had been deposited on the surface during the treatment. Wires were gently washed with deionised distilled water and their surface layer was dissolved in a minimal volume of diluted $\mathrm{HCl}$. After removal of the wires, a small amount of concentrated $\mathrm{HCl}$ was added to the solution and it was boiled for couple of minutes in order to dissolve of larger particles totally. The resultant solution was diluted, and chromium was determined.

The total amount of voluminous $\mathrm{Al}(\mathrm{OH})_{3}$ precipitate formed during the treatment in the $\mathrm{MB}$ and the $\mathrm{CC}$ was collected, decanted from the water phase and weighed. After that, the precipitate was homogenised by stirring, and sample aliquots of $25.0 \mathrm{~m} \ell$ were taken. Sampled precipitate was weighed and dissolved in the $\mathrm{NaOH}$. The solution was filtered through black ribbon filter paper and analysed for $\mathrm{Cr}(\mathrm{III})$ and $\mathrm{Cr}(\mathrm{VI})$. Black powder residue at the filter paper was treated with $\mathrm{HCl}$ and heated. Chromium was determined in solution thus obtained.

\section{Analytical methods}

Chromium(VI) was determined in the model solution samples and in the dissolved $\mathrm{Al}(\mathrm{OH})_{3}$ precipitate by means of the chelationextraction method for hexavalent chromium according to Method 218.4 described in EPA (1983). The analyses were performed by flame atomic absorption spectroscopy using a VARIAN SpectrAA-20, in an air-acetylene flame.

In solutions obtained by dissolving of $\mathrm{Al}(\mathrm{OH})_{3}$ and composite wires, $\mathrm{Cr}(\mathrm{III})$ was determined by FAAS, applying Method 218.1 (EPA, 1983), in a nitrous oxide-acetylene flame.

\section{Results and discussion}

The results of $\mathrm{pH}$ monitoring in the of $\mathrm{Cr}(\mathrm{VI})$ model solutions, with initial $\mathrm{pH}: 1.00,2.00,3.00,4.00$ and 5.00, during the treatment by the MAlC in the semi-flow system, are shown in Fig. 3.

At the start of the treatment, the $\mathrm{pH}$ of model solutions rapidly increased (Fig. 3). After that, the $\mathrm{pH}$ gradient decreased, and after about $60 \mathrm{~min}$, the $\mathrm{pH}$ of all the model solutions became almost equal (Fig. 3). In the second half of the treatment, there was no significant $\mathrm{pH}$ variation $(\mathrm{pH}$ was about 9$)$.

The $\mathrm{pH}$ changes of the model solutions during the treatment were a function of their initial value. This dependence is shown in 


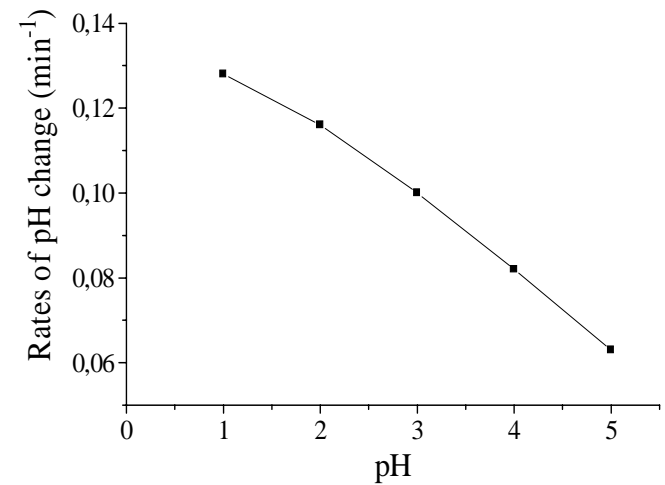

Figure 4

The rates of $\mathrm{pH}$ change over the period of the treatment from 0 to $60 \mathrm{~min}$, as a function of initial $\mathrm{pH}$ of model solutions

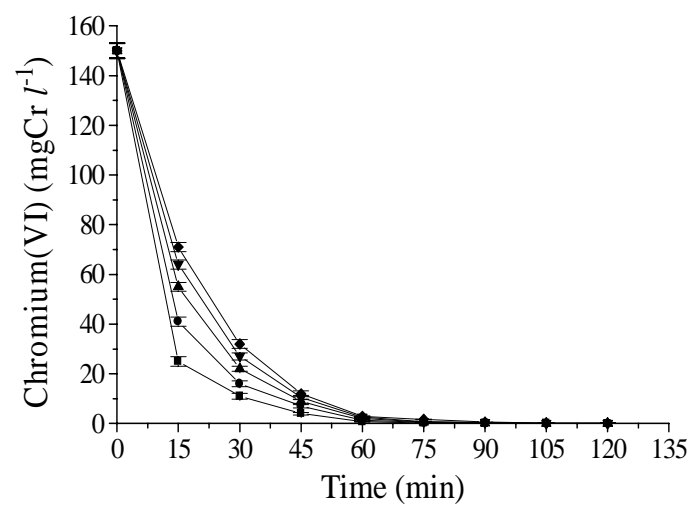

Figure 5

Changes of $\mathrm{Cr}(\mathrm{VI})$ concentration in the model solutions with initial $\mathrm{pH}: 1.00(\bullet), 2.00(\bullet), 3.00(\mathbf{\Delta}), 4.00(\mathbf{\nabla})$ and $5.00(\bullet)$, during the treatment by the MAIC, in the semi-flow system at $20^{\circ} \mathrm{C}$. Error bars represent the standard deviation of triplicate sample means values

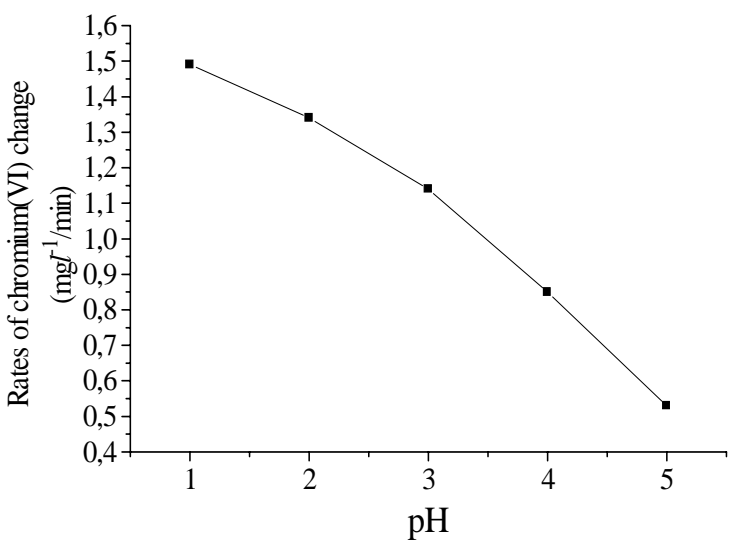

Figure 6

The rates of change of $\mathrm{Cr}(\mathrm{VI})$ concentration in period of the treatment from 0 to $60 \mathrm{~min}$, in function of initial $\mathrm{pH}$ of model solutions

Fig. 4, as a rate of $\mathrm{pH}$ change as a function of initial $\mathrm{pH}$, over the period of treatment from 0 to $60 \mathrm{~min}$.

The rates of $\mathrm{pH}$ change significantly decreased with increasing initial $\mathrm{pH}$. However, after $60 \mathrm{~min}$ the $\mathrm{pH}$ values of all model solutions became equal, even though the $\mathrm{pH}$ varied considerably at the start (from 1 to 5). Figure 4 shows that the rate of $\mathrm{pH}$ change for model Solution I was twofold greater than for Solution V, under given conditions.

Results shown are in accordance with findings from previous studies of MAlC treatments (Purenovic, 1992, Bojic, 1997; Purenovic et al., 1998; Novakovic et al., 1998; Bojic et al., 2001; Bojic, 2002), where, after a particular period of time, the $\mathrm{pH}$ of solutions always became about 9 , irrespective of initial $\mathrm{pH}$. The MAl spontaneously reacts with water owing to very negative reduction potential in contrast to a pure metal, and this process is intensified by acids and bases. After neutralisation, $\mathrm{Al}(\mathrm{III})$ and $\mathrm{OH}^{-}$ ions appeared in almost stoichiometrical amounts, because of continual formation of insoluble $\mathrm{Al}(\mathrm{OH})_{3}$, and $\mathrm{pH}$ became constant.

The results of changes of $\mathrm{Cr}(\mathrm{VI})$ concentration in model solutions with initial concentration of $\mathrm{Cr}(\mathrm{VI}) 150 \mathrm{mg} \cdot \ell^{-1}$ and $\mathrm{pH}$ : $1.00,2.00,3.00,4.00$ and 5.00, during the MAlC treatment in the semi-flow system, are shown in Fig. 5.

Figure 5 shows that at the beginning of the treatment in all model solutions, concentrations of $\mathrm{Cr}(\mathrm{VI})$ rapidly decreased, and after about 60 min total concentration decay was about 3 orders of magnitude. During the second half of the treatment, the next 60 min, change of $\mathrm{Cr}(\mathrm{VI})$ concentration was significantly smaller.

The rates of change of $\mathrm{Cr}(\mathrm{VI})$ concentration in function of $\mathrm{pH}$, for the period 0 to $60 \mathrm{~min}$, are shown in Fig. 6 .

With decreasing initial $\mathrm{pH}$, the rates of change of $\mathrm{Cr}(\mathrm{VI})$ concentration regularly increased. Acidity of model solution increased the MAl dissolution and reduction efficiency of the composite (Bojic, 1997; Purenovic et al., 1998). Because of that, in the first half of the treatment, efficacy of the composite was greater in model solutions with lower $\mathrm{pH}$. Considering that the $\mathrm{pH}$ of model solutions became equal after $60 \mathrm{~min}$ (Fig. 3), efficacy of the composite became equal, too (period from 60 to 120 min, Fig. 5). Concentrations of $\mathrm{Cr}(\mathrm{VI})$ in model solutions at the end of the treatment by the MAlC are shown in Table 1, as an average with standard deviation.

\begin{tabular}{|c|c|}
\hline \multicolumn{2}{|c|}{$\begin{array}{c}\text { TABLE 1 } \\
\text { Concentrations of } \mathrm{Cr}(\mathrm{VI}) \text { in } \\
\text { model solutions at the end } \\
\text { of the treatment }\end{array}$} \\
\hline $\begin{array}{c}\text { Model } \\
\text { solution }\end{array}$ & $\begin{array}{c}\mathrm{Cr}(\mathrm{VI}) \pm \text { SD } \\
{\left[\mathrm{mgCr} \cdot \ell^{-1}\right]}\end{array}$ \\
\hline I & $0.007 \pm 0.003$ \\
II & $0.021 \pm 0.008$ \\
III & $0.03 \pm 0.011$ \\
IV & $0.036 \pm 0.014$ \\
V & $0.04 \pm 0.012$ \\
\hline
\end{tabular}

Results in Table 1 demonstrate that final concentrations of $\mathrm{Cr}(\mathrm{VI})$ at the end of the treatment were very low in all model solutions. Their values depended on initial $\mathrm{pH}$, and it was shown that the concentration difference between model Solutions I and V was about one order of magnitude.

Analysis of the surface area of the composite wires after the treatment showed the presence of metal chromium, deposited in the form of a black amorphous powder. Amounts of metal chromium on composite wires are shown in Table 2. Averages with standard deviation are shown.

Presented results reveal that the amounts of metal chromium deposited on the composite wires after treatment were rather low. 


\begin{tabular}{|c|c|}
\hline \multicolumn{2}{|c|}{$\begin{array}{c}\text { TABLE } 2 \\
\text { Amounts of metal chro- } \\
\text { mium on composite } \\
\text { wires }\end{array}$} \\
\hline $\begin{array}{l}\text { Model } \\
\text { solution }\end{array}$ & $\begin{array}{l}\text { Chromium } \\
\pm \text { SD [mg] }\end{array}$ \\
\hline I & $17.4 \pm 2.1$ \\
\hline II & $17.1 \pm 1.8$ \\
\hline III & $16.6 \pm 2.0$ \\
\hline IV & $17.5 \pm 1.8$ \\
\hline $\mathrm{V}$ & $15.8 \pm 1.4$ \\
\hline
\end{tabular}

By comparing the results, small differences were noted among model solutions, which indicate that deposition of chromium was not affected by initial $\mathrm{pH}$.

Testing of $\mathrm{Al}(\mathrm{OH})_{3}$ precipitate showed that it comprised major amounts of $\mathrm{Cr}(\mathrm{VI})$, which were removed during the treatment. In precipitate, the chromium was in the reduced forms, as $\mathrm{Cr}(\mathrm{III})$ and metal chromium. However, a small amount of $\mathrm{Cr}(\mathrm{VI})$, was also coprecipitated during the treatment.

The amounts of chromium, $\mathrm{Cr}(\mathrm{III})$ and $\mathrm{Cr}(\mathrm{VI})$ in the $\mathrm{Al}(\mathrm{OH})_{3}$ precipitate are presented in Table 3. Averages with standard deviation are shown.

\begin{tabular}{|c|c|c|c|}
\hline \multicolumn{4}{|c|}{ TABLE 3 } \\
$\begin{array}{c}\text { Amounts of chromium forms in } \mathrm{Al}(\mathrm{OH})_{3} \text { precipi- } \\
\text { tate at the end of the treatment }\end{array}$ \\
\hline $\begin{array}{c}\text { Model } \\
\text { solution }\end{array}$ & $\begin{array}{c}\text { Metal chromium } \\
\pm \text { SD [mg] }\end{array}$ & $\begin{array}{c}\text { Cr(III) } \pm \text { SD } \\
\text { [mgCr] }\end{array}$ & $\begin{array}{c}\text { Cr(VI) } \pm \text { SD } \\
\text { [mgCr] }\end{array}$ \\
\hline I & $903 \pm 12.5$ & $273 \pm 8.5$ & $8.5 \pm 1.6$ \\
II & $697.5 \pm 10.4$ & $432 \pm 9.5$ & $14.4 \pm 2.2$ \\
III & $541.5 \pm 10.5$ & $591 \pm 12.0$ & $18.0 \pm 2.3$ \\
IV & $408 \pm 9.5$ & $712.5 \pm 12.4$ & $23.6 \pm 2.5$ \\
V & $316.5 \pm 8.4$ & $802 \pm 14.4$ & $27.4 \pm 2.1$ \\
\hline
\end{tabular}

It can be noted that the amount of each chromium species in $\mathrm{Al}(\mathrm{OH})_{3}$ precipitate depends on the initial $\mathrm{pH}$ of the model solution. With increasing initial $\mathrm{pH}$, the amount of metal chromium in the precipitate decreases, and the content of $\mathrm{Cr}$ (III) content increases. Content of $\mathrm{Cr}(\mathrm{VI})$ in a precipitate is two orders of magnitude lower than metal chromium and $\mathrm{Cr}(\mathrm{III})$, and it increases with initial $\mathrm{pH}$.

The presence of metal chromium and $\mathrm{Cr}$ (III)-hydroxide in precipitate indicates that the mechanism of removal of $\mathrm{Cr}(\mathrm{VI})$ from water phase is based mainly on reduction. This reduction process is especially intensified by oxidation characteristics of $\mathrm{Cr}(\mathrm{VI})$, the redox potential of which is $+1.33 \mathrm{~V}$ (Rieger, 1987). It is presumed that reduction of $\mathrm{Cr}(\mathrm{VI})$ occurs on the very surface of the composite wires, while the water phase passes through the composite chamber.

The assumption is that at the beginning of each treatment, when reduction activity of the composite is greater, chromium is mainly removed from the water phase in totally reduced form - metal chromium. Considering that the MAl was continuously dissolved during the treatment, with permanent regeneration of its surface, reduced chromium (amorphous black powder) was co-precipitated

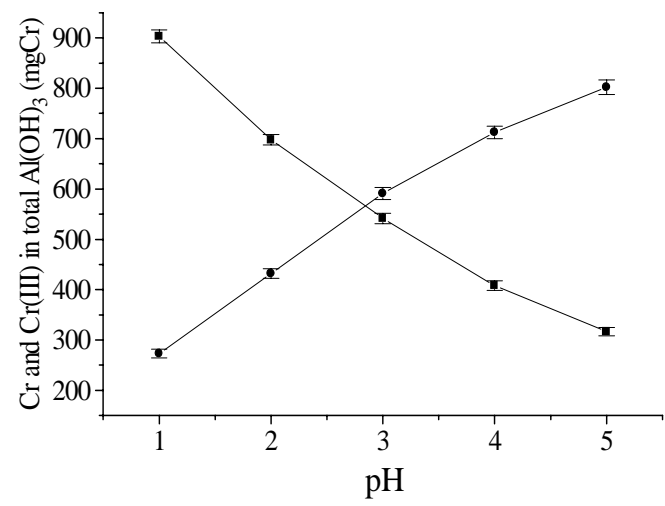

Figure 7

Amounts of metal chromium (•) and $\mathrm{Cr}(\mathrm{III})(\bullet)$ in $\mathrm{Al}(\mathrm{OH})$ precipitate at the end of the treatment as a function if initial $\mathrm{pH}$ of model solution

by $\mathrm{Al}(\mathrm{OH})_{3}$. That is the reason why small amounts are found on the composite wires at the end of each treatment.

The amount of elementary chromium deposited during the treatment, is dependent on the initial $\mathrm{pH}$ of the model solution. Decrease of metal chromium with increasing initial $\mathrm{pH}$ is graphically shown by curve (-) in Fig. 7, based on the results shown in Table 3.

The residual part of $\mathrm{Cr}(\mathrm{VI})$ from the water phase was reduced to $\mathrm{Cr}(\mathrm{III})$, precipitated in the form of $\mathrm{Cr}(\mathrm{OH})_{3}$. This can be explained by the fact that $\mathrm{Cr}(\mathrm{III})$ appears later during the treatment, which is multiple related to $\mathrm{pH}$ value of environment. Initially, composite reduction activity decreases with increasing $\mathrm{pH}$. The second phenomenon is the increase of concentration of the $\mathrm{OH}^{-}$ ion, which reacts with $\mathrm{Cr}(\mathrm{III})$ and forms insoluble $\mathrm{Cr}(\mathrm{OH})_{3}$. Additionally, with increasing $\mathrm{OH}^{-}$ion concentration, the amount of colloid $\mathrm{Al}(\mathrm{OH})_{3}$, co-precipitation reagent, increases because concentrations of $\mathrm{OH}^{-}$and $\mathrm{Al}^{3+}$ ions exceed the solubility product of $\mathrm{Al}(\mathrm{OH})_{3}$ (Cotton and Wilkinson, 1972; Martin, 1991).

All the above-mentioned phenomena interrupt reduction of $\mathrm{Cr}(\mathrm{VI})$ during the $\mathrm{Cr}(\mathrm{III})$ stage, because of the formation of very stable, insoluble $\mathrm{Cr}(\mathrm{OH})_{3}$, which cannot contact with composite wires. Figure 7 shows that the amount of chromium removed from water phase as $\mathrm{Cr}(\mathrm{OH})_{3}$ regularly increased with initial $\mathrm{pH}$ of model solutions.

Amounts of $\mathrm{Cr}(\mathrm{VI})$ co-precipitated by $\mathrm{Al}(\mathrm{OH})_{3}$, were rather low in all model solutions, and depended on initial $\mathrm{pH}$. Start of $\mathrm{Cr}(\mathrm{VI})$ co-precipitation was accompanied by sufficient formation of colloid $\mathrm{Al}(\mathrm{OH})_{3}$. Those conditions were achieved earlier in model solutions with higher initial $\mathrm{pH}$, and necessary periods were from 25 to $40 \mathrm{~min}$ (Fig. 3). Considering that, at the moment when coprecipitation of $\mathrm{Cr}(\mathrm{VI})$ had started (Fig. 5), its concentration was greater in model solutions with higher initial $\mathrm{pH}$, the outcome was an increase of $\mathrm{Cr}(\mathrm{VI})$ in $\mathrm{Al}(\mathrm{OH})_{3}$ precipitate with initial $\mathrm{pH}$ (Table 3).

In contrast with a previous study (Purenovic et al., 1998), which had dealt with removal of $\mathrm{Cr}(\mathrm{VI})$ from wastewaters under stationary conditions, the results obtained in this work by applying semi-flow systems showed major efficacy of the MAlC. Purenovic et al. (1998) had treated effluents discharged by the chromiumplating industry. Experiments were done on a series of wastewater samples, with adjusted $\mathrm{Cr}(\mathrm{VI})$ concentration to $145.0 \mathrm{mgCr} \cdot \ell^{-1}, \mathrm{pH}$ between 1 and 11 and sample aliquots of $1.0 \ell$. The samples were subjected to four composite wires, under stationary conditions, over a period of $60 \mathrm{~min}$. The results are shown in Fig. 8.

Purenovic et al. (1998) used $0.035 \mathrm{mgCr}(\mathrm{VI}) \cdot \mathrm{mm}^{-2}$ of geometric surface areas of wires. The same conditions were used in this 


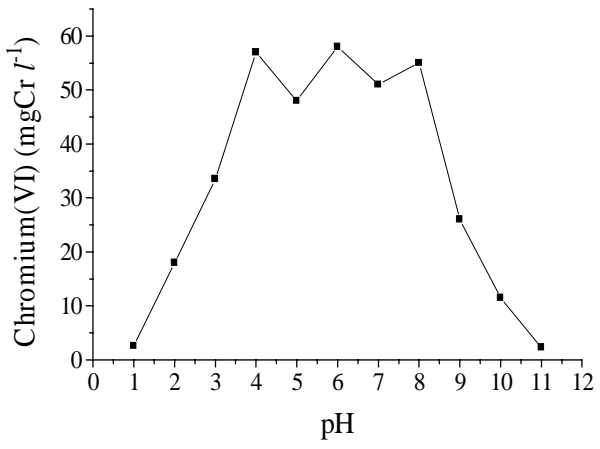

Figure 8

$\mathrm{Cr}(\mathrm{VI})$ concentration after 60 min of the MAIC treatment in stationary conditions, in function of $\mathrm{pH}$. Initial concentration of $\mathrm{Cr}(\mathrm{VI})$ in all samples was $145.0 \mathrm{mgCr} \cdot \ell^{-1}$ (Purenovic et al., 1998)

study as well. Comparing the results in Figs. 5 and 8, it is shown that the semi-flow system achieved greater efficacy of the MAlC. In $60 \mathrm{~min}$ period in stationary conditions, reduction of $\mathrm{Cr}(\mathrm{VI})$ concentration was one log or less; in contrast to this, in the SFS reduction it was about 3 logs.

Comparing the SFS with stationary conditions, where pollutants make contact with the composite surface only by diffusion, the water continually "filters" through the composite wires, which increases the probability of contact between a pollutant and the composite. The convection in the semi-flow system accelerates diffusion of $\mathrm{Al}(\mathrm{III})$ and $\mathrm{OH}^{-}$ions from the wire surface, and accordingly dissolution of the MAl, which additionally increases the composite activity.

\section{Conclusions}

The results of the study presented here show that the micro-alloyed aluminium composite, used in the semi-flow system, is a powerful device for the removal of $\mathrm{Cr}(\mathrm{VI})$ from wastewaters, over a wide range of initial $\mathrm{pH}$.

Behaviour of composites in an aqueous environment is significantly influenced by $\mathrm{pH}$, due to the negative reduction potential as well as amphoteric characteristics of micro-alloyed aluminium. The $\mathrm{pH}$ affects both composite efficacy and mechanism of action. During the treatment, $\mathrm{pH}$ of solutions increases to a specific value, and after that it becomes constant. It could be said that composite and water represent a specific buffer system, which may adjust the $\mathrm{pH}$ of any aqueous solution to a value of about 9 .

Total decline of $\mathrm{Cr}(\mathrm{VI})$ concentration after $120 \mathrm{~min}$ of the MAlC treatment is appreciable in all model solutions, and it is about 5 logs. The rate of change of $\mathrm{Cr}(\mathrm{VI})$ concentration is the highest at the start of treatment in all model solutions, because of low $\mathrm{pH}$. During the treatment, the rate of change declines, as composite efficacy decreases, and for a long period, change of $\mathrm{Cr}(\mathrm{VI})$ concentration is in the range of one log. Differences in final concentrations of $\mathrm{Cr}(\mathrm{VI})$ between model solutions are about one order of magnitude, which illustrates the influence of initial $\mathrm{pH}$ on the treatment efficacy.

Considering that $\mathrm{Cr}(\mathrm{VI})$ removed from the water phase was found in $\mathrm{Al}(\mathrm{OH})_{3}$ in the form of metal chromium and $\mathrm{Cr}(\mathrm{III})$ hydroxide, the mechanism of $\mathrm{Cr}(\mathrm{VI})$ removal is mainly based on reduction. Differences in the ratio of metal chromium and $\mathrm{Cr}$ (III) amounts in $\mathrm{Al}(\mathrm{OH})_{3}$ between model solutions, indicate that, in the case of $\mathrm{Cr}(\mathrm{VI})$, initial $\mathrm{pH}$ influences the mechanism of the composite action, far more than its efficacy. $\mathrm{Cr}(\mathrm{VI})$ was present in very low amounts in the precipitate, and that fact is very important for further handling of the precipitate.

After 120 min of the treatment, concentrations of $\mathrm{Cr}(\mathrm{VI})$ in all model solutions were below maximum allowed concentrations for drinking water $\left(0.05 \mathrm{mgCr} \cdot \ell^{-1}\right)$, and after 70 to $80 \mathrm{~min}$, depending on initial $\mathrm{pH}, \mathrm{Cr}(\mathrm{VI})$ concentrations were about those allowed for rivers of Class III $\left(0.5 \mathrm{mgCr} \cdot \ell^{-1}\right)$.

The presented semi-flow system enables the total volume of model solution to pass through the composite chamber multiple times, which is a simplified simulation of the flow conditions. The SFS increases the efficacy of the MAlC considerably, compared to the stationary conditions.

The $\mathrm{pH}$ of the water phase at the end of the composite treatments is usually about 9 , and under these conditions solubility of aluminium is great (Martin, 1991). Therefore, it is always necessary to adjust the $\mathrm{pH}$ of purified water to about 6.5 , and to filter it to reduce $\mathrm{Al}$ concentration to within the allowed range, in order to prevent contamination of the environment.

\section{Acknowledgements}

This study was supported by the Ministry of Science and Technology of Serbia and Montenegro, Matherials and Chemical Technology: No 0279 .

\section{References}

ALLIANE A, BOUNATIRO N, CHERIF AT and AKRETCHE DE (2001) Removal of chromium from aqueous solution by complexation-ultrafiltration using a water-soluble macroligand. Water Res. 35 (9) 23202326.

BARCELOUX DG (1999) Chromium. J. Toxicol. Clin. Toxicol. 37 (2) 173-194.

BARNHART J (1997) Occurrences, uses, and properties of chromium. Regul. Toxicol. Pharmacol. 26 (1) 3-7.

BOHDZIEWICZ J (2000) Removal of chromium ions(VI) from underground water in the hybrid complexation-ultrafiltration process. Desalination 129 227-235.

BOJIC A (1997) Physicochemical Phenomena at Heterogenic Spontaneous Electrocatalysis of Some Organic and Inorganic Compounds in Aqueous Solutions by Applying The Solid Metal Catalyst Based on Microalloyed Aluminium. M.Sc. Thesis, Department of Chemistry, University of Niš (in Serbian). 124 pp.

BOJIC A (2002) The Mechanism of Influence of Electrochemically Active Microalloyed Aluminium Based Composite on Microorganisms in Aqueous Medium. Ph.D. Thesis, Department of Chemistry, University of Niš (in Serbian). 114 pp.

BOJIC A, PURENOVIC M, KOCIC B, PEROVIC J, URSIC-JANKOVIC J and BOJIC D (2001) The inactivation of Escherichia coli by microalloyed aluminium based composite Facta Universitatis. 2 115-124.

COONEY E, LUO B, PATTERSON JW and PETROPOULOU C (1992) Toxicity reduction methodologies. In: Ford DL (ed.) Water Quality Management Library Vol. 3. Lancaster, PA: Technomic. 109-181.

COTTON AF and WILKINSON G (1972) Basic Inorganic Chemistry. John Wiley and Sons, New York.

DESPIC A, DRA $\bullet$ IC D, PURENOVIC M and CIKOVIC N (1976) Electrochemical properties of aluminium alloys containing indium and thallium. J. Appl. Electrochem. 6 529-536.

EPA (1983) Methods for chemical analysis of water and wastes. In: William A Telliard (ed.) Office of Water Test Methods and Guidance. US EPA, Washington, DC (on CD-ROM).

HASSMANOVA V, VANECKOVA J and BOUSOVA K (2000) Occupational diseases caused by chromium and its compounds. Acta. Med. 43 33-36.

KANERVA L, JOLANKI R, ESTLANDER T, ALANKO K and SAVELA A (2000) Incidence rates of occupational allergic contact dermatitis caused by metals. Am. J. Contact. Dermat. 11 (3) 155-160. 
LEINONEN H and LEHTO J (2001) Purification of metal finishing waste waters with zeolites and activated carbons. Waste Manage. Res. 19 (1) 45-57.

LOWE W (1970) The Origin and Characteristics of Toxic Wastes With Particular Reference to the Tetal Industries. Water Pollution Control, London. 270-280.

MARTIN RB (1991) $\mathrm{Fe}^{3+}$ and $\mathrm{Al}^{3+}$ hydrolysis equilibria. J. Inorg. Biochem. 44 141-147.

MESUERE K and FISH W (1992) Chromate and oxalate adsorption on goethite 1. Calibration of surface complexation models. Environ. Sci. Technol. 26 2357-2364.

NOVAKOVIC M, PURENOVIC M, PEROVIC J, MILJKOVIC M, RANÈIC S and BOJIC A (1998) Waste water refinement by the solid metal catalyst. Acta. Biol. Iug. 33 363-366.

PATERSON JW (1975) Wastewater Treatment Technology. Ann Arbour Science, Michigan. 43-58.

PURENOVIC M (1978) Influence of Some Alloying Components on Electrochemical Behaviour of System Al-O Layer Electrolyte. Ph.D. Thesis, Faculty of Technology, University of Belgrade (in Serbian). 187 pp.
PURENOVIC M (1980) Yu-Patent 1334/80.

PURENOVIC M (1992) Yu-Patent 669/92.

PURENOVIC M, BOJIC A, STANISAVLJEVIC M and VELJKOVIC N (1998) Chrome waste water treatment in wide $\mathrm{pH}$ range on new solid catalyser. 2nd Intl. Conf. "Advanced Wastewater Treatment, Recycling and Reuse”. Milan, Italy, September 14-16. 927-930.

RIEGER PH (1987) Electrochemistry. Prince-Hall, New Yersey.

SELVI K, PATTABHI S and KADIRVELU K (2001) Removal of Cr(VI) from aqueous solution by adsorption onto activated carbon. Bioresour. Technol. 80 (1) 87-89.

STANDARD METHODS (1995) Standard Methods for the Examination of Water and Wastewater (19th edn.) American Public Health Association, Washington, DC.

TENORIO JA and ESPINOSA DC (2001) Treatment of chromium plating process effluents with ion exchange resins. Waste Manage. 21 (7) 637-642.

VOYUTSKY S (1978) Colloid Chemistry. MIR, Moscow. 
